\title{
Changing media representations of mental health
}

\author{
G. Philo
}

The Glasgow Media Group has published the first major study in this country on media coverage of mental health (Philo, 1996). This research examines both the content of press, television and films and how these relate to public beliefs about mental illness. It involved an extensive content analysis plus a series of focus group interviews. The results show clearly that ill-informed beliefs on, for example, the association of schizophrenia with violence can be traced directly to media accounts.

It was also found that beliefs derived from the media could sometimes overwhelm direct experience in this area. For example, one interviewee had visited a hospital in Glasgow many times to see a relative who had been a patient there for 25 years. She associated mental illness with violence and cited 'TV films' as the source of her beliefs. "Texas Chainsaw Massacre, Freddy's Revenge, Nightmare on Elm Street, Psycho-I watch a lot of them, I like all they ones". She was asked specifically if the feeling about violence came from the films rather than what she had seen when visiting. She replied: "Oh aye - every time I was up visiting, I never saw any violence and he was in a big open ward".

Other interviewees related their beliefs about mental illness to characters from television soap operas such as Channel Four's Brookside. The important point is that beliefs derived from fictional accounts clearly affected attitudes in real life. One interviewee gave her views about the mentally ill as: "They could be alright one minute and then just snap - I'm kind of wary of them ... That Fatal Attraction, she was as nice as nine pence and then ....".

Such comments can reveal very deep levels of fear. Another interviewee wrote in her reply that mentally ill people were "quite likely to be violent - split personality usually tend to be violent". She went on to write that "I would tend to be more wary as some mentally ill people can be very clever and devious". The source of her views was given as "probably from TV and newspapers, I think!". And she went on in her interview to comment that: "Hungerford, that type of thing - anything you see on the news, it's likely to be violent when it is connected with mentally ill people."
The new research also includes interviews with users of services who describe the damaging effects of the climate of fear which surrounds mental illness. This research is already known to many in the Royal College of Psychiatrists. Three thousand members and fellows have now signed a petition noting the research results and asking that the media alter their practices in the reporting and presentation of mental health. The petition specifically asked that there should be a major debate within the media on these issues and that codes of conduct be produced to guide journalists in this area. The petition was sent to the controllers and management of broadcasting and the press. It was followed by individual letters to senior broadcasters in both the $\mathrm{BBC}$ and the major independent companies.

Their response so far has been quite unacceptable. Not one television company has as yet initiated new programmes to discuss these issues or offered to develop specific guidelines for journalists as a result of the petition. Some respondents simply denied the problem. A senior commissioning editor for Channel Four wrote that "I am not aware of the same old stereotypes appearing on Channel Four programmes" (Letter, 22 February 1996). This theme was echoed by the response from the Head of the BBC Drama Group who wrote "I am not aware of prejudice within the BBC TV Drama Group . . . I would be interested to hear examples of stereotypes within our screen output" (Letter, 26 February 1996). He was thinking of more positive programmes such as Taking Over the Asylum. However, in a recent episode of Birds of a Feather, a lead character commented: "Eccentric? Wearing odd socks is eccentric. Ordering ten grands worth of double glazing you can't pay for is stark bonkers" (BBC 1, 20 July 1996). Similarly the controllers of ITV should watch their output for children. including Carlton's Transylvanian Pet Shop. Here a character said recently: "We'd be mad to let you have this money and we are actually stark staring mad. Ha Ha Hee Hee" (and they hop off making 'mad' noises; ITV, 16 July 1996). In case anyone doubts that such coverage is routine, on the same show one week later a character commented "I said I am stark staring bonkers" (23 July 1996). 
In the Glasgow research, an interviewee who was a user of services commented specifically on the effect of children's programmes:

"Something that occupies my thoughts is sitting down with my child in front of the telly and the number of images that are about being crazy and a nutter on children's TV, and Looney Tunes has a regular slot and it may sound harmless but almost every other phrase they use is to be 'crazy' or a 'nutter', whether it is the presenter or the characters in the films. I wonder what happens to children when they grow up and have these images put into them."

It is clear that such issues do not concern the makers of many TV programmes. Some responses to the petition showed senior broadcasters to be as ill-informed in this area as some members of the public. Scottish Television replied by pointing to their past programmes on 'mental illness' notably those on 'Down's syndrome' and 'Parkinson's disease'. One key factor in preventing broadcasters from taking up this issue is the belief that mental health is somehow not 'mainstream' television. Yet one of the most interesting responses to the petition was from an executive editor of $\mathrm{BBC}$ radio, who commented on the States of Mind series which was broadcast over six months on radio and television in 1995. She commented that "the response from listeners and viewers calling our helplines and requesting the mental health directory was huge... Any fears that such programming deters viewers is quite unfounded, the subject is one that does attract an audience" (Letter, 22 February 1996).

Members of the College should therefore not be reluctant to insist that mental health is a major social issue and that some media coverage of it is a serious problem that must be addressed. The Glasgow research shows clearly the climate of fear which surrounds the subject of mental illness. One organiser at a drop-in centre for users of services told us how the assumed link between violence and mental illness affected enquiries which they received: "I had one woman asking me if (she) was safe living in (her) own house 'Am I going to get my throat cut?' She said she loved her son ... but she was terrified, she wanted to know if her daughter would be safe. Her son was on medication and he was due to come home. He had no history of violence . . . and this is common".

The new research also shows the impact of media images on users of services themselves. The most powerful negative effect seemed to be in the area of self-definition and the stigma developed and reinforced by media portrayals. As one interviewee put it, "You see a programme and it shows a very bad image of what it feels like yourself and then you think what are my neighbours going to think about it".

Another group member described to us in detail his feelings when he was given the label of being schizophrenic: "When I was told I was schizophrenic, I was very intimidated by it - I thought I was some sort of monster. I didn't actually feel like a monster, but when they said I was schizophrenic, I just couldn't believe it . . . It's just such a hell of a word, you know and it's got a hell of a stigma ... I just thought it was Jekyll and Hyde. I was just one of those people I'm characterising this morning (for having incorrect beliefs about mental illness) ... . but you're really more likely to hurt yourself - what was blasting through my head was you'll never get a job, you'll never get a sick line, you'll have nowhere to live. It was just going through my head. kill yourself".

This group member was asked about where his original ideas on mental illness had come from, he replied: "Jane Eyre was my mother's favourite programme and I think I got it from her. We watched it faithfully every Saturday night. She (a character in the story) was insane and she ran around screaming and shouting and burnt the house down - and that instilled real fear in me ... They'll burn the house down, they'll stab you, they'll kill you - that's what I thought myself until I realised I had a problem myself". He also described the changes in his social relationships: "When my neighbours knew that I was schizophrenic, they were worried about getting into the lift with me they didn't want to be in a confined space, and they wouldn't open the door to me... My window cleaner asked me would you not hit me over the head with the hammer' - I had to reassure him that 'look mate, I'm not violent' and he was telling the neighbours. It rots you, it just rots you".

Many psychiatrists have experience with their own patients of the damage caused by this climate of fear. The media is in part responsible for this and must therefore be confronted with the consequences of its own actions. Many members of the College do indeed believe this, which is why they signed the petition. The response of some sections of the media has apparently been that they 'did not want to be lectured to' on this subject. But the College must stand firm in the face of such attitudes. In the past there has been much criticism of media coverage of groups such as black and gay people. After long campaigns, both the press and television did indeed change their approach to such minorities. The controllers of media and the makers of programmes were told very firmly they had to do so. It is time that the College joined with all the other groups in the area of mental health to demand the necessary changes in this area.

\section{Reference}

PHIL. G. (ed.) (1996) Media and Mental Distress. London: Longman.

Greg Philo, Department of Sociology, University of Glasgow, 61 Southpark Avenue, Glasgow G12 8LF 